Ankara Ecz. Fak. Mec.

12. 105 (1982)
J. Fac. Pharm Ankara

12. 105 (1982)

\title{
Rutenyum Elektrotla Hidrokinonun Anodik Oksidasyonun İncelenmesi
}

\author{
Investigation of Anodic Oxidation of Hydroquinone Using \\ Ruthenium Electrode.
}

İnci BİRYOL*

\section{GİRIŞ}

Platin grubu metallerinden olan rutenyumun elektrokimyasal özellikleri ile ilgili araştırmalar oldukça yakın zamanlarda başlamış ve bu tip çalışmalar ilerledikçe bu metal, elektrot olarak önem kazanmiştır.

Soy metallerin elektrot olaylarında katalitik etkisinin incelenmesi sonucunda Platin-Rutenyum alaşımlarında bu etkinin Platine oranla daha fazla olduğu saptanmıştır (1) Ayrıca Pt grubu metalleri arasında hidrojen adsorpsiyon 1sısının, 6, yüzeyin hidrojenle kaplanma oranına bağlılı̆̆ı incelenerek (2) Pd, Pt ve Ir için 0 nın küçük değerlerinde adsorpsiyonun kuvvetli, 0 nın büyük değerlerinde ise zayıf olduğu; Rh ve Ru için ise adsorpsiyon şiddetinin 6 arttıkça sürekli azaldığı yani hidrojenin, bütün yüzey kaplanma oranları için yüzeye zayıf bağlarla bağlandı̆̆

Hidrojen adsorpsiyonunda elektrot-elektrolit faz sinirinda $\mathrm{H}_{\mathrm{ads}}+\mathrm{H}_{2} \mathrm{O} \leftrightharpoons \mathrm{H}_{3} \theta_{-}^{+}+$e dengesinin kurulduğu kanıtlanmıştır (3). Kinonik yapılı bileşiklerin redoks mekanizmasında elektron geçişimi ile birlikte hidrojenasyon ve dehidrojenasyon da olduğundan bu çalışmanın 1. bölümünde Rutenyum elektrotun kinonik

* Analitik Kimya Bilim Dalı Eczacılık Fakültesi Ankara Üniversitesi. 
yapılı bileşiklerin redoks mekanizmasındaki rolünü incelemek üzere ilk kez rutenyum elektrot kullanılarak hidrokinonun oksidasyonu araştırılmış ve hidrokinonun miktar tayini koşulları saptanmıştır.

MATERYAL ve YÖNTEM

$\mathrm{Bu}$ araştırmada sürekli değişen potansiyelde voltametri yöntemi uygulanmış (4) ve yavaş süpürme hızlarında çalışılmıştır. Yavaş süpürme yöntemi 1-100 mV/'sn lik potansiyel değişme hızlarını kapsayan yarı kararlı hal yöntemi olup süpürme hızının kararlı hal kinetiğinin kurulmasına yetecek kadar yavaş, safsılıkların elektrot yüzeyinde toplanıp akım-potansiyel ilgisini etkilemesini önleyecek kadar da hızlı olduğu varsayılır. Buradan çıkarılacak sonuçlar kinetik parametrelerin hıza bağlı olmadığı süpürme hızı aralığında çalışıldı̆̆ında geçerlidir (5). Uygun potansiyel değişme hızı, çalışılan sistemin tipine ve saflık durumuna da bağlıdır. Bu çalışmada ikizkenar üçgen dalgası şeklinde ve zamanla lineer değişen potansiyeller uygulanmıştır. Eğriler Tacussel PRG-3 potansiyostatik polarograf ile elde edilmiştir.

Deneylerde kullanılan $\mathrm{Ru}$ çalışma elektrodu Engelhard (Sutton-Surrey) firmasından getirtilen $1 \mathrm{~mm}$ çapındaki rutenyum telden, yardimci elektrot ise Johnson Mattheey Co. Ltd. firmasindan sağlanan $0,5 \mathrm{~mm}$ çapında platin telden kendimiz tarafından yapılmıştır. Referans elektrot olarak doymuş kalomel elektrot kullanılmiştır.

Tekrar edilebilirliğin ve deneye uygun bir yüzey halinin saptanabilmesi için katı elektrotlarla yapılan çalışmalarda elektroda uygulanacak ön işlemin önemi büyüktür ve bu işlem her metalin kendine özgü olmaktadır. Rutenyum elektrot $1 \mathrm{~N} \mathrm{H}_{2} \mathrm{SO}_{4}$ içerisinde potansiyostattan $-20 \mathrm{mV}$ luk bir gerilim 5 dakika uygulanarak redüklenmiş ve sonra yıkanıp kurulanarak değişik deneylerde değişik potansiyellerde (örneğin 300, 500, 1200 ve 1350 mV.) oksitlenmiştir. Bu tip işlem görmüş elektrotlar çeşitli süpürme hızları ile yapılan deneylerde kullanılmıştır. Miktar tayini için potansiyel $6 \mathrm{mV} / \mathrm{dk}$ hızla değiştirilmiş ve elektrot $-20 \mathrm{mV}$ da 5 dakika redüklendikten sonra deney çözeltisine alınmış ve sistemin denge potansiyeli değerine ulaşılınca deneye başlanmıştır. 
Deneyler ve ön işlemler 3 kollu, pyrex camdan yapılmış deney hücrelerinde yapılmıştır. Deneylerde kullanılan $\mathrm{H}_{2} \mathrm{SO}_{4}, \mathrm{HC}_{10}$ ve Hidrokinon B.D.H (analar) dir. KC1 Merck'dir. (İletkenlik suyundan kristallendirilerek saflaştırılmıştır).

$\mathrm{CH}_{3} \mathrm{COOH}$ B. D. H (analar); $\mathrm{CH}_{3} \mathrm{COONa} .3 \mathrm{H}_{2} \mathrm{O}$ B. D. H (analar $\mathrm{Na}_{2} \mathrm{HPO}_{4}$ Merck (pure); $\mathrm{NaH}_{2} \mathrm{PO}_{4}$ Merck (pure) dir.

\section{B U L G U LA R}

Rutenyum elektrodun platine oranla hidrojen adsorplama kapasitesinin büyük ve adsorpsiyon enerjisinin küçük olduğu $(6,7)$ bulgusuna ve her iki elektrodun da değişik potansiyellerde değişik nitelikte oksitlerle kaplı olduğu gerçeğine dayanılarak bu iki metalin hidrokinon oksidasyonundaki davranışları karşılaştırılmıştır.

Şek. 1.a da $-20 \mathrm{mV}$ da 5 dak. redüklenmiş rutenyum elektrotla $1 \mathrm{~N} \mathrm{H}_{2} \mathrm{SO}_{4}$ içerisinde $100 \mathrm{mV} /$ sn süpürme hızı ile elde edilmiş eğri görülmektedir. Burada oksidasyon dalında 550, 1050, $1350 \mathrm{mV}$ da basamaklar belirmiş olup bunlar önceki çahşmalarımızdaki (8) bulgulara uymaktadır. Şek. 1.b deki eğri $-20 \mathrm{mV}$ da 5 dak. redüklenmiş rutenyum elektrotla $10^{2} \mathrm{M}$ hidrokinon içeren $1 \mathrm{~N}^{2} \mathrm{H}_{2} \mathrm{SO}_{4}$ içerisinde $100 \mathrm{mV} / \mathrm{sn}$ potansiyel değişme hızı ile elde edilmiştir. Burada ilk oksitlenme basamağ $150 \mathrm{mV}$ dolayından başlamakta ve $1100 \mathrm{mV}$ yakınlarında sınır akımına ulaşılmaktadır. Eğrinin geri dönüşünde redüksiyon hemen dönüş potansiyelinden başlamayıp bir süre daha oksidasyon gözlenmektedir. Redüksiyon bu dalda $550 \mathrm{mV}$ dan sonra görülmektedir. Bunun nedeni çözeltiye daldırılan elektrot yüzeyinin hidrokinon molekülleri ile örtülmesi, oksidasyon ilerledikçe açılan yüzeyin de oksitlenmeye başlaması olarak düşünülebilir. Şek. 1.a da $780 \mathrm{mV}$ a kadar olan oksidasyon dalındaki sınır akımı 0.8-1 mA dolayında, şek. 1.b. de ise aynı potansiyel bölgesindeki sınır akımı değeri yine aynı olup $750 \mathrm{mV}$ dan sonra önemli bir akım artışı olmaktadır. Bu da $750 \mathrm{mV}$ da başlayan basamağın hidrokinonun oksidasyon basamağı olduğunu göstermektedir. Ĕ̆rilerin redüksiyon dalları karşılaştırıldığında $550 \mathrm{mV}$ da başlayan sınır akımı değerinin $1 \quad \mathrm{~N}_{2} \mathrm{H}_{2} \mathrm{SO}_{4}$ içerisinde $0.8-1.0 \mathrm{~mA}$ dolayında olduğu $10^{-2}$ $M$ hidrokinon içerisinde ise aynı bölgedeki sınır akımının 1.2-1.4 mA olduğu görülüyor. Aradaki fark bu basamakta elektrodun yüzey 


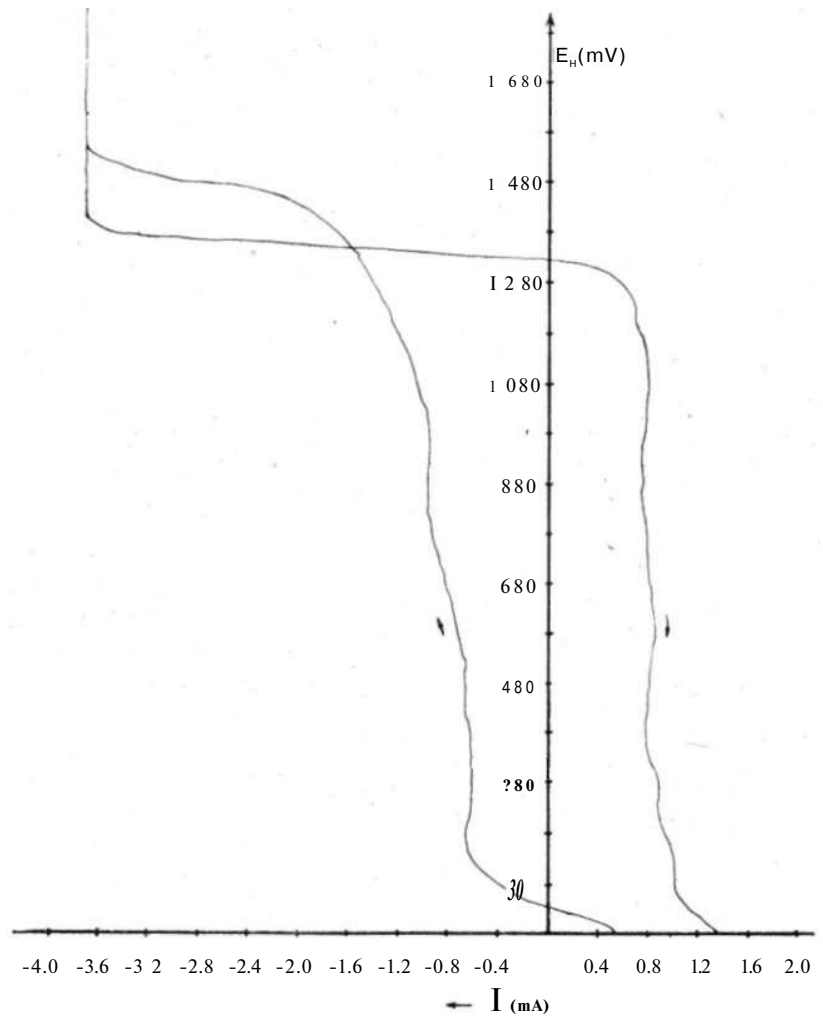

Şek. 1a) $1 \mathrm{~N} \mathrm{H}_{2} \mathrm{SO}_{4}$ içerisinde Rutenyum elektrotla $100 \mathrm{mV} /$ sn süpürme hızında elde edilmiş eğri.

oksidi ile birlikte hidrokinonun oksidasyon ürününün de redüklendiğini göstermektedir. Şek. 2 (a) $1 \mathrm{~N} \mathrm{H}_{2} \mathrm{SO}_{4}$ içerisinde 5 dakika $4450 \mathrm{mV}$ da oksitlenmiş ve 15 dakika $350 \mathrm{mV}$ da redüklenmiş $\mathrm{Pt}$ elektrotla $100 \mathrm{mV} / \mathrm{s} n$ potansiyel değişme hızı ile elde edilmiş eğriyi göstermektedir. $750 \mathrm{~m}$ ve $1100 \mathrm{mV}$ daki iki basamak platinin yüzey oksitleri ile ilgili olup $1500 \mathrm{mV}$ daki akım artışı oksijen çıkışına karşı gelmektedir. (9) Şek. 2.b yine aynı ön işlem uygulanmış Pt elektrotla $1 \mathrm{~N} \mathrm{H}_{2} \mathrm{SO}_{4}$ içeren $10^{-2} \mathrm{M}$ hidrokinon çözeltisi içerisinde elde edilmiştir. Potansiyel değişme hızı $100 \mathrm{mV} / \mathrm{sn}$ dir. Burada $750 \mathrm{mV}$ da tek bir basamak görülmektedir. Ve şek. 2. a da bu basamağın sınır akımı değeri $0.08 \mathrm{~mA}$ iken burada $4 \mathrm{~mA}$ olup hidrokinonun oksit- 


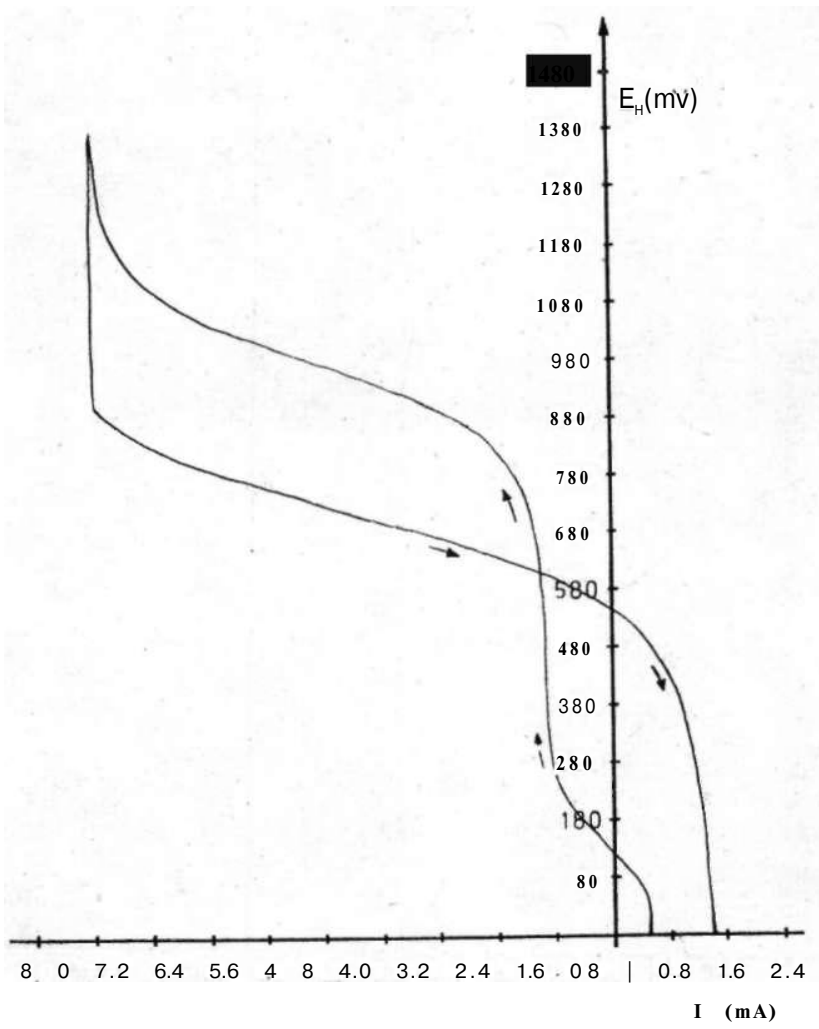

Şek. 1b) $10^{-2} \mathrm{M}$ hidrokinon $+\mathrm{I} \mathrm{N} \mathrm{H}_{2} \mathrm{SO}_{4}$ içerisinde Rutenyum elektrotla $100 \mathrm{mV} / \mathrm{sn}$ süpürme hızındaki polarizasyon eğrisi.

lendiği anlaşılmaktadır. Bu eğrinin geri dönüşünde izlenen potansiyel aralı̆̆ında eğri katodik bölgeye geçmemiştir.

Şek. 3 de $10^{-3} \mathrm{M}$ hidrokinon, $1 \mathrm{M} \mathrm{KCl}$ ve $\mathrm{Na}_{2} \mathrm{H} \mathrm{PO}_{4} / \mathrm{NaH}_{2} \mathrm{PO}_{4}$ tamponu içeren $(\mathrm{pH}=7.2)$ çözeltide $75 \mathrm{mV} / \mathrm{dak}$ potansiyel süpürme hızı elde edilmiş eğriler görülmektedir. Şek. 3.a, -20 mV da 5 dakika redüklenip denge potansiyeli olan $245 \mathrm{mV}$ da 15 dakika oksitlenmiş rutenyum elektrodun polarizasyon eğrisini göstermektedir. Burada $300 \mathrm{mV}$ dolayında başlayıp $550 \mathrm{mV}$ yakınlarında sınır akımına ulaşan bir basamak görülmektedir. Şek. 3.b deki eğri yine aynı şekilde ön işlem uygulanmış platin elektrotla elde edilmiştir. Burada oksidasyon basamağının başlangıcı 450-500 mV daki akım artışı ile 


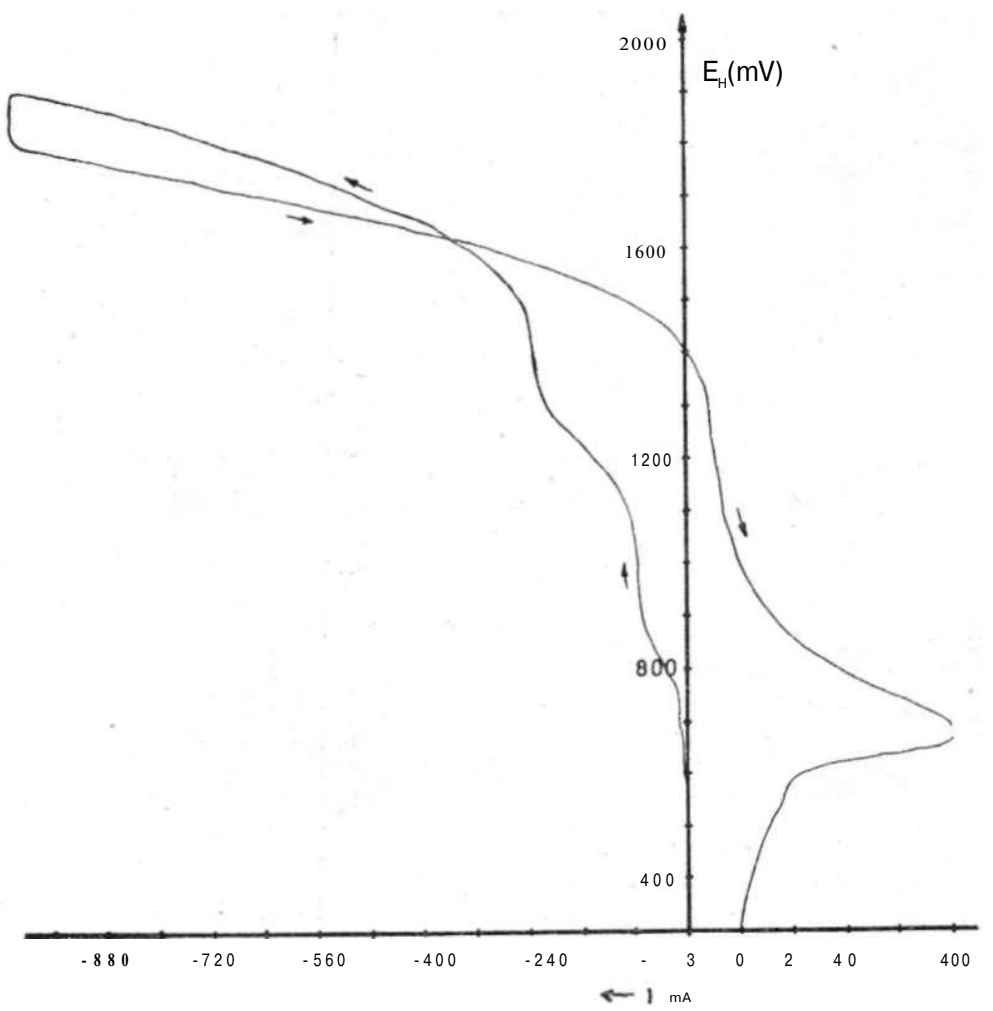

Şek. 2a) $1 \mathrm{~N} \mathrm{H}_{2} \mathrm{~S} \mathrm{O}_{4}$ içerisinde platin elektrotla $100 \mathrm{mV} / \mathrm{sn}$ süpürme hızında elde edilmiş eğri.

kendini göstermektedir fakat sınır akımı gözlenmemektedir. Şek. 3.a ve 3.b nin karşılaştırılması platin elektrotla elde edilmiş eğrideki akım şiddetinin rutenyumla elde edilmiş olandan daha küçük olduğunu göstermektedir. Bunun nedeni platinde ön işlem sırasında adsorplanmış hidrojenin yüzeye daha sıkı bağlanmış olması ve oksidasyonu bir ölçüde engellemesidir.

Şek. 4 deki eğriler $-20 \mathrm{mV}$ da 5 dakika redüklenip $-500 \mathrm{mV}$ da 15 dakika oksitlenmiş rutenyum elektrotla $75 \mathrm{mV} / \mathrm{dk}$ süpürme hızı ile elde edilmişlerdir. 1 nolu eğri $3.10^{-4} \mathrm{M}$ hidrokinon içeren $1 \mathrm{~N} \mathrm{H}_{2} \mathrm{SO}_{4}$ içerisinde, 2 nolu eğri $1 \mathrm{~N} \mathrm{H}_{2} \mathrm{SO}_{4}$ içerisindeki polarizas- 


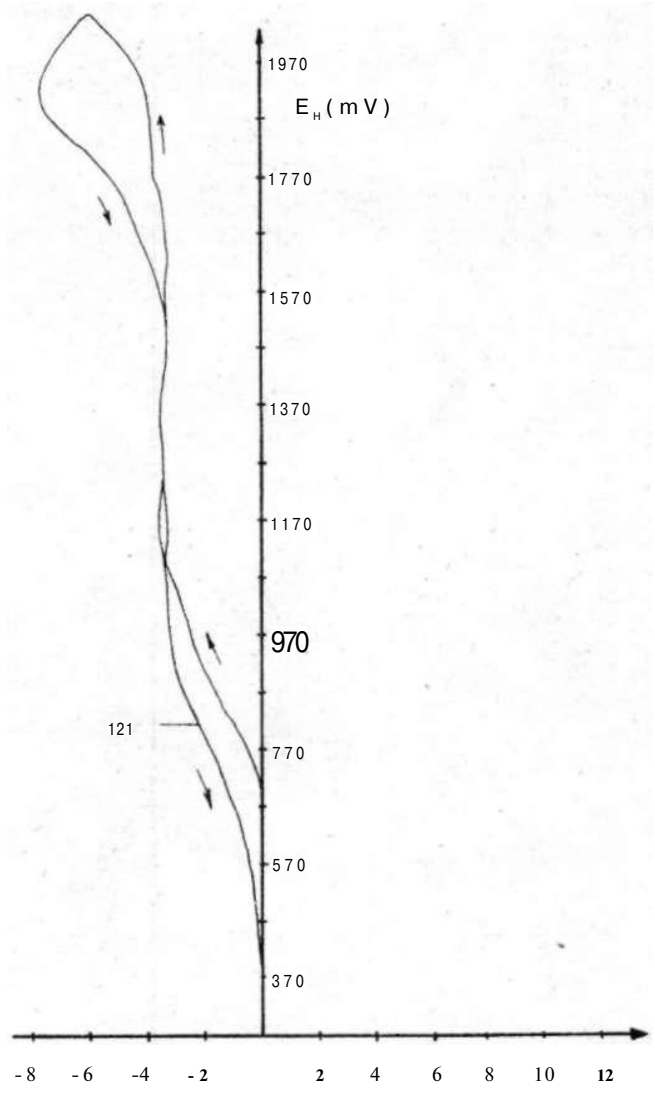

Şek. 2b) $\mathbf{1 0}^{-2} \mathrm{M}$ hidrokinon $+1 \mathrm{~N} \mathrm{H}_{2} \mathrm{SO}_{4}$ içerisinde platin elektrotla $100 \mathrm{~m} \mathrm{~V} \mid$ sn süpürme hızında elde edilmiş eğri.

yon eğrisidir. Hidrokinon çözeltisinde $700 \mathrm{mV}$ dolayındaki basama$\breve{g} 1 \mathrm{n}$ bu maddenin oksidasyonu ile ilgili olduğu ve dönüşte de $850 \mathrm{mV}$ da oksidasyon ürününün redüklendiği iki eğrinin karşılaştırılmasından anlaşılmaktadır.

Şek. 5 de destek elektrolitinin tür ve konsantrasyonunun ve oldukça yüksek anodik potansiyellere çıkılarak bu potansiyellerde 


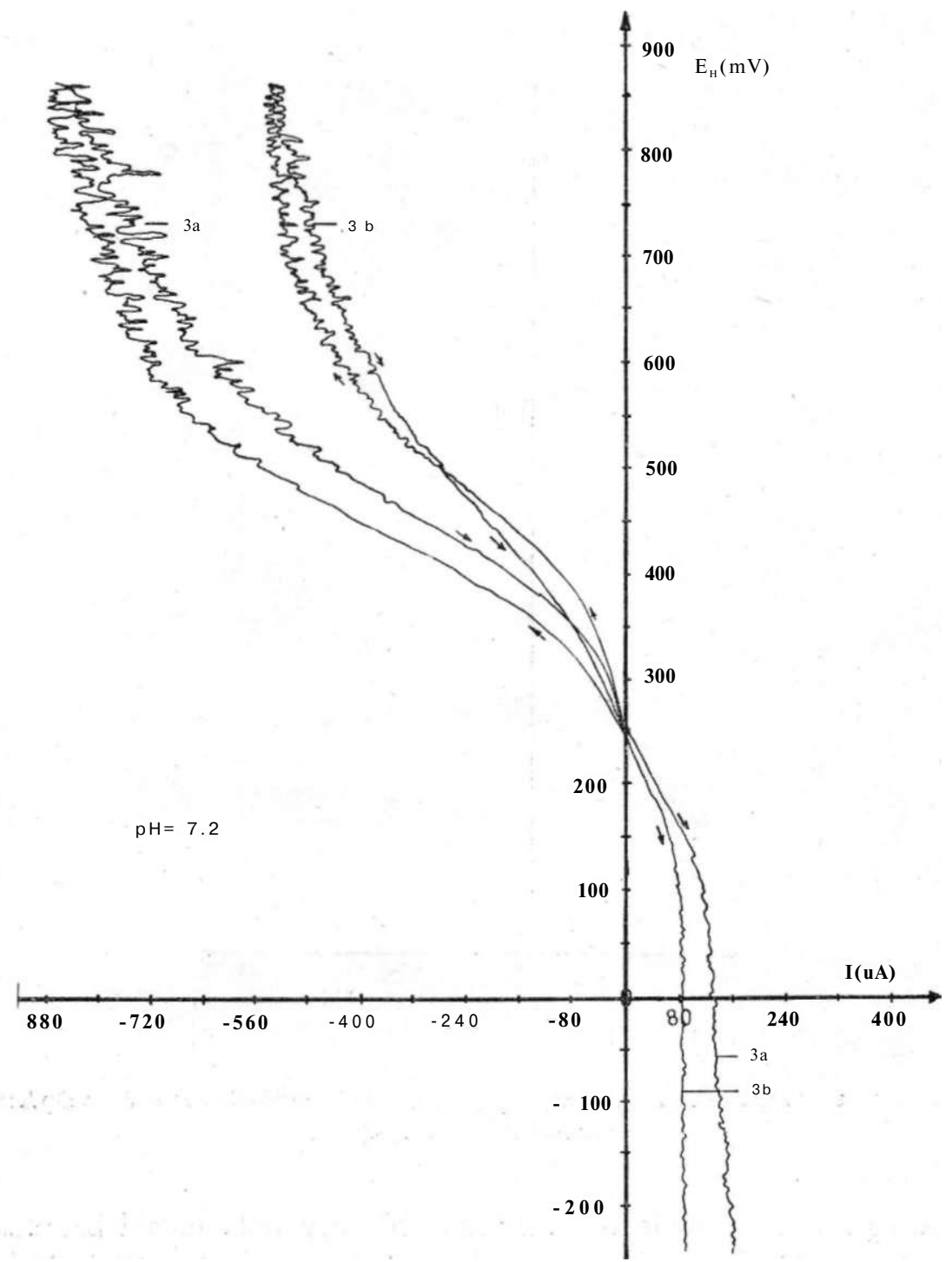

Şek. 3) $\mathrm{pH}=7,2$ fosfat tamponu $+10^{-3} \mathrm{M}$ hidrokinon $+1 \mathrm{M} \mathrm{KCl}$ içerisinde $75 \mathrm{mV} /$ dk süpürme hızında Rutenyum (3a) ve platin (3b) elektrotla elde edilmiş eğriler.

elektrot yüzeyinde oluşan değişik oksit tabakalarının etkileri incelenmiştir. 1 nolu eğri $-20 \mathrm{mV}$ da redüklenmiş rutenyum elektrotla 


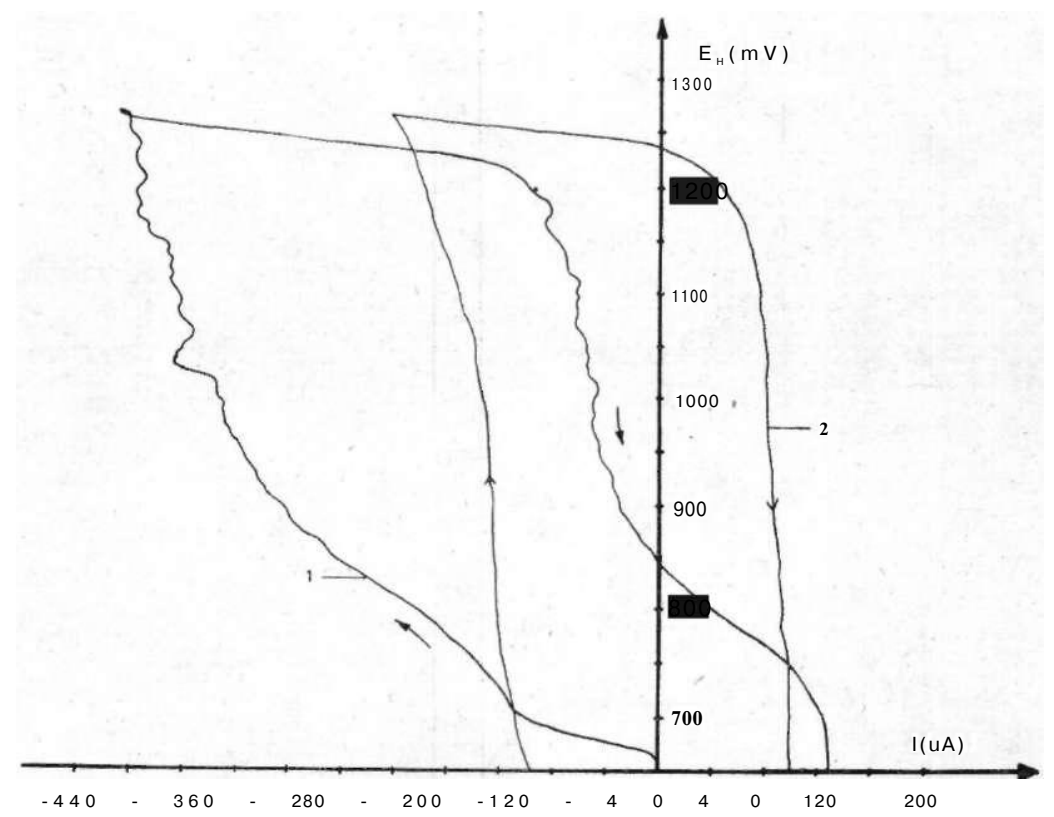

Şek. 4) $3.10^{-4} \mathrm{M}$ hidrokinon $+\mathbf{1} \mathrm{N} \mathrm{H}_{2} \mathrm{SO}_{4}$ (eğri 1), ve $1 \mathrm{~N} \mathrm{H}_{2} \mathrm{SO}_{4}$ (eğri 2) içerisinde $\mathbf{7 5 0}$ $\mathrm{mV} / \mathrm{dk}$ süpürme hızında rutenyum elektrotla elde edilmiş eğriler.

$2 \mathrm{~N} \mathrm{H}_{2} \mathrm{SO}_{4}+10^{-2} \mathrm{M}$ hidrokinon içeren çözeltide 2 nolu eğri aynı ön işlem uygulanmış rutenyum elektrotla $1 \mathrm{~N} \mathrm{HC10_{4 }}+10^{-2} \mathrm{M}$ hidrokinon içerisinde, 3 nolu eğri ise yine $1 \mathrm{~N} \mathrm{HC10_{4 }}+10^{-2} \mathrm{M} \mathrm{hid-}$ rokinon içerisinde fakat $-20 \mathrm{mV}$ da redüklenip $+300 \mathrm{mV}$ da 15 dakika oksitlenmiş rutenyum elektrotla elde edilmiştir. Redüklenmiş elektrotla elde edilmiş olan 1 ve 2 nolu eğrilerde ön işlem sırasında adsorplanmış olan hidrojenin oksidasyonuna karşı gelen bir basamak $200 \mathrm{mV}$ yakınlarında görülmekte, + $300 \mathrm{mV}$ da oksitlenmiş elektrotla elde edilen eğride bu basamak görülmemektedir. Hidrokinon oksidasyonu her üç eğride de $800 \mathrm{mV}$ dolaylarında başlamaktadır. $1480 \mathrm{mV}$ dolayındaki basamak rutenyum elektrodun $\mathrm{RuO}_{4} \mathrm{e}$ oksitlenme basamağıdır (8). Eğrilerin redüksiyon dalında 580-600 mV dolaylarına kadaroksidasyon sürmekte ancak bu potansiyellerde redüksiyon başlamaktadır. Şek. 1 de daha az pozitif potansiyellerden geri dönülmüş olmasına karşın redüksiyon akımlarının şek. 5 dekine yakın olması 


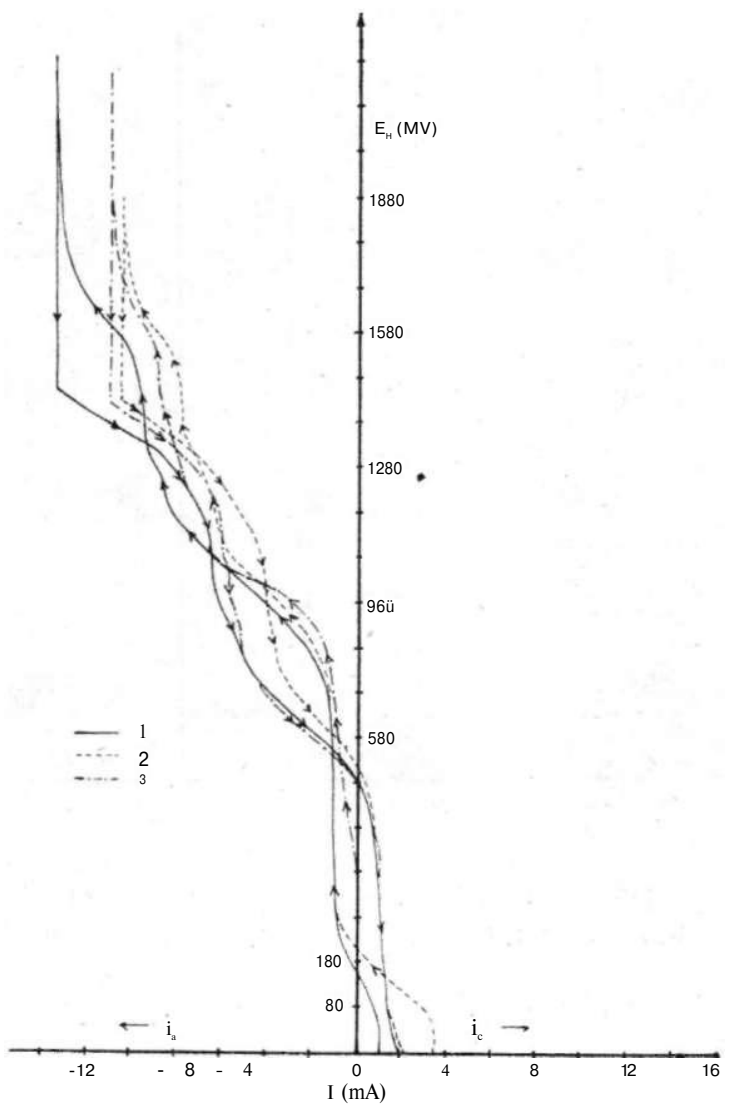

Şek. 5) $10^{-2} \mathrm{M}$ hidrokinon $+\mathrm{a} \mathrm{N} \mathrm{H}_{2} \mathrm{SO}_{4}, 10^{-2} \mathrm{M}$ hidrokinon $+1 \mathrm{~N} \mathrm{HC} \mathrm{I} \mathrm{O}_{4}$ çözeltilerinde $100 \mathrm{mV} / \mathrm{sn}$ süpürme hızında değişik ön ișlem görmüş rutenyum elektrotla elde edilmiş eğriler.

elektrot yüzeyinde oluşan tabakaların reaksiyona gösterdiği direncin aşağı yukarı aynı veya oluşma süresinin kısa olması nedeniyle fazla bir engelleyici etki gösteremiyecek kadar ince olduğunu açıklamaktadir.

\section{Hidrokinon Oksidasyonunda konsantrasyon-sinir Akimi} İlgisi :

Analitik amaçlar için potansiyel $6 \mathrm{mV} / \mathrm{dk}$ lık bir hızla değiştirilerek değişik konsantrasyonlarda hidrokinon içeren $1 \quad \mathrm{~N}_{2} \mathrm{H}_{2} \mathrm{SO}_{4}$ 
$(\mathrm{pH}=0.2) ; 1 \mathrm{M} \mathrm{KCl}+$ asetik asit $(\mathrm{pH}=2.9) ; 1 \mathrm{M} \mathrm{KCI}+$ asetik asit/ asetat tamponu $(\mathrm{pH}=4.5) ; 1 \mathrm{M} \mathrm{KCI}+\mathrm{Na}_{2} \mathrm{HPO}_{2} /$ $\mathrm{NaH}_{2} \mathrm{PO}_{4}$ tamponu $(\mathrm{pH}=6) ; 1 \mathrm{M} \mathrm{KCI}+\mathrm{Ha}_{2} \mathrm{HPO}_{2} / \mathrm{NaH}_{2} \mathrm{PO}_{2}$ tamponu ( $\mathrm{pH}=7.2)$ çözeltileri içerisinde polarizasyon eğrileri elde edilmiştir. Çözelti magnetik karıştırıcı ile 600 devir/dk sabit hızla karıştırılmıştır. Elektrot $1 \quad \mathrm{~N}_{2} \mathrm{H}_{2} \mathrm{SO}_{4}$ içerisinde $-20 \mathrm{mV}$ da 5 dak. redüklenip deney çözeltisine alınmış ve denge potansiyelini alıncaya kadar oksitlenerek deneye başlanmıştır.

Her pH da hidrokinon ilave etmeden yalnız tampon ve KCI içeren çözeltide bir eğri elde edilmiş, $10^{-2}, 5.10^{-3}, 2.10^{-3}, 10^{-4} \mathrm{M}$ hidrokinon içeren çözeltilerde elde edilen sınır akımından destek elektroliti içerisinde elde edilen değer çıkarılarak sınır akımı konsantrasyon grafikleri çizilmiştir. Şek. 6,7,8,9 ve 10 bu eğrileri ve sınır akımı konsantrasyon grafiklerini göstermektedir. Tablo I de her pH bölgesindeki denge potansiyeli, sınır akımı potansiyel bölgesi ve sınır akımı değerleri verilmiştir.

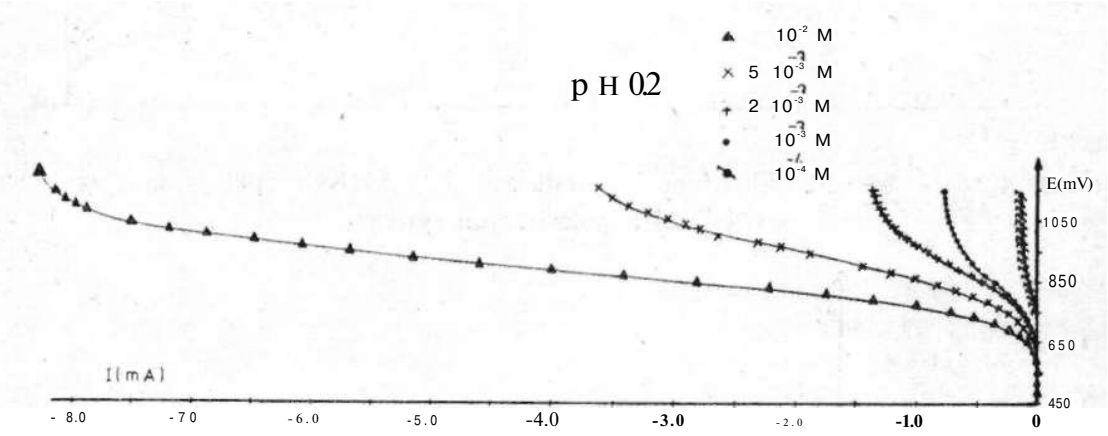

Şek. 6) $10^{-4}-10^{-2} \mathrm{M}$ hidrokinon $+1 \mathrm{~N} \mathrm{H}_{2} \mathrm{SO}_{4}(\mathrm{pH}-\mathbf{0 , 2})$ içerisinde elde edilen polarizasyon eğrileri.

Şek. 6a, 7a, 8a, 9a ve 10a daki konsantrasyon-sınır akımı grafiklerinde $5 \mathrm{pH}$ bölgesi için de tablodaki konsantrasyon aralığında lineerlik görülmektedir. Yalnız pH $=6.0$ da ara değerlerde tekrarlanabilirlik yeterli değildir. Buradaki doğru iki konsantrasyon değeri, bir de sıfır noktası alınarak çizilmiştir. 


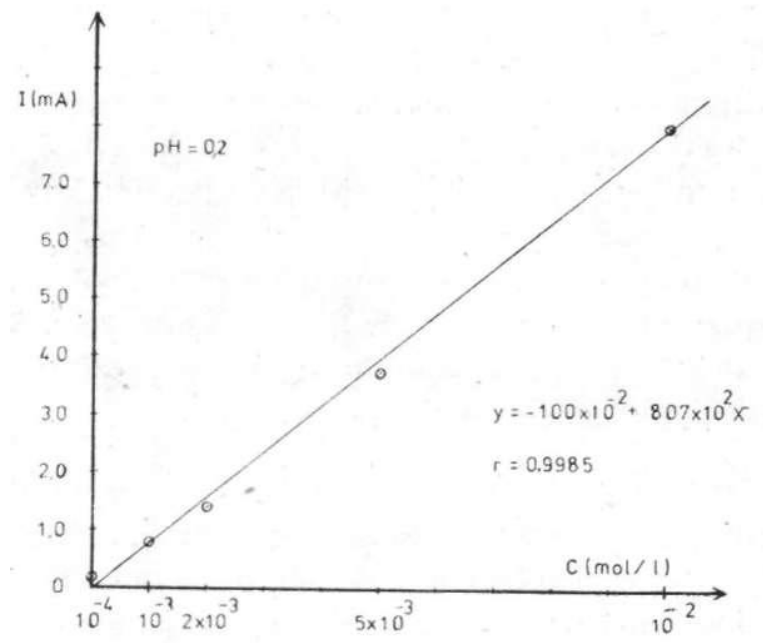

Şek. 6a) Şek. 6 daki eğrilerin sınır akımı-konsantrasyon grafiği.

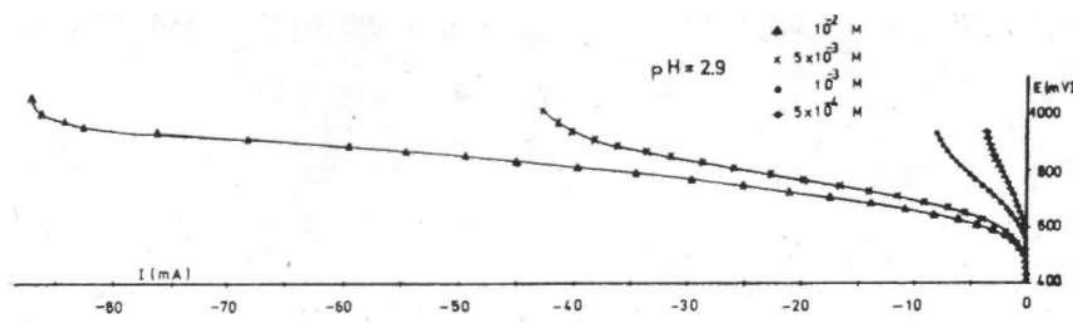

Şek. 7) $5.10^{-4}-10^{-2} \mathrm{M}$ hidrokinon + asetik asit $+\mathbf{1} \mathrm{M} \mathrm{KCr}(\mathrm{pH}=\mathbf{2}, 9)$ içerisinde elde edilen polarizasyon eğrileri.

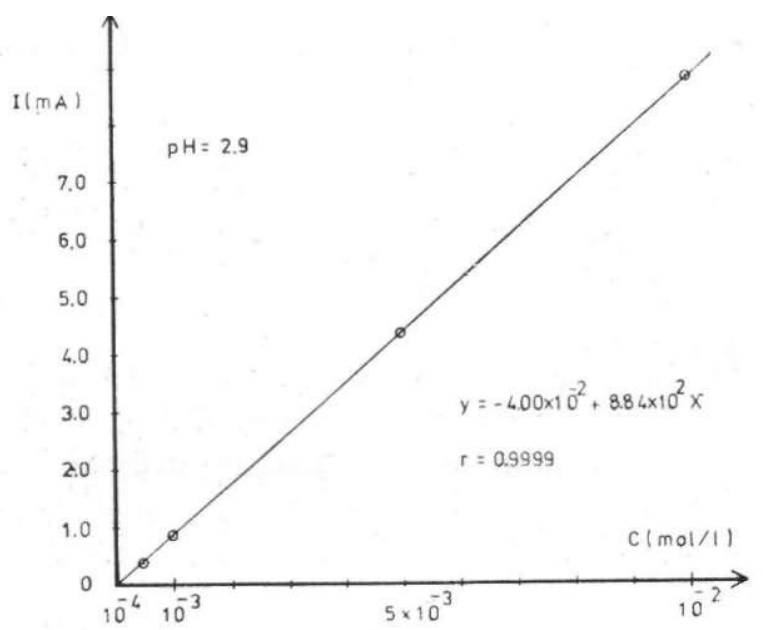

Şek. 7a) Şek. 7 deki sınır akımı-konsantrasyon grafiği. 


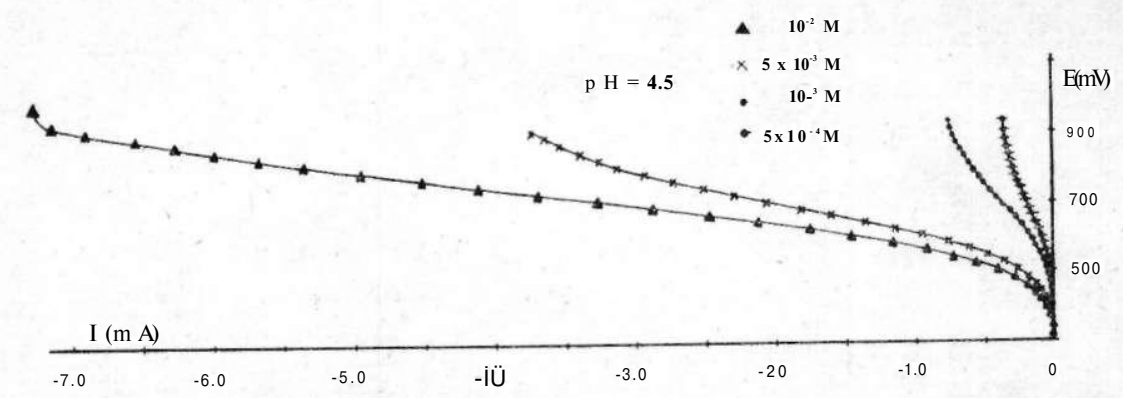

Şek. 8) $5 \cdot 10^{-4}-10^{-2} \mathrm{M}$ hidrokinon + asetat tamponu + KCI ( pH = 4.5) içerisinde elde edilen polarizasyon eğrileri.

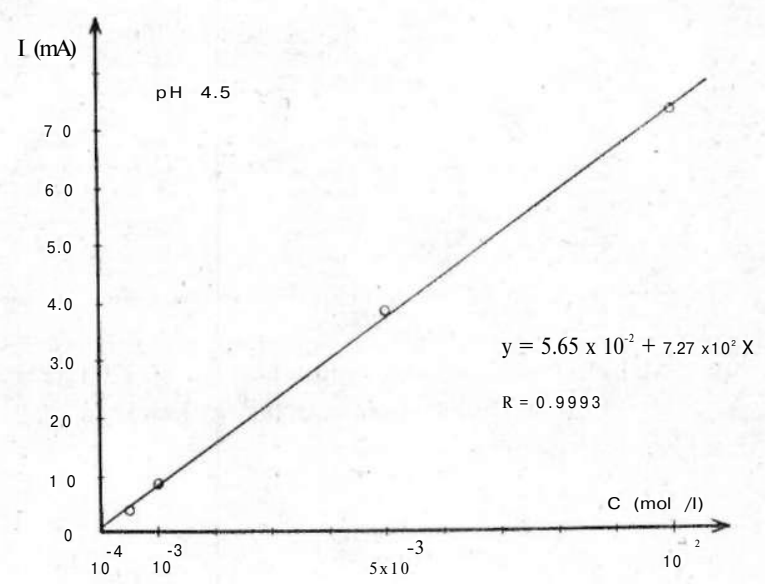

'Şek. 8a) Şek. 8 den yararlanılarak çizilen sınır akımı-konsantrasyon grafiği.

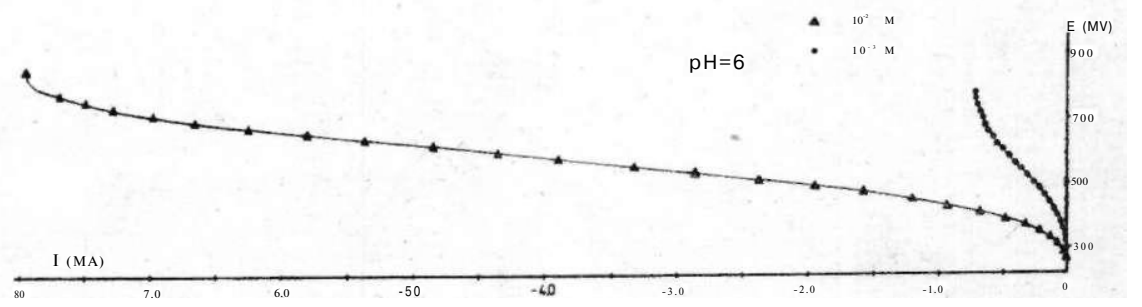

Şek. 9) $10^{-2}-10^{-3} \mathrm{M}$ hidrokinon + fosfat tamponu $+1 \mathrm{M} \mathrm{KCl}$ içerisinde $(\mathrm{pH}=6,0)$ elde edilen polarizasyon eğrileri. 


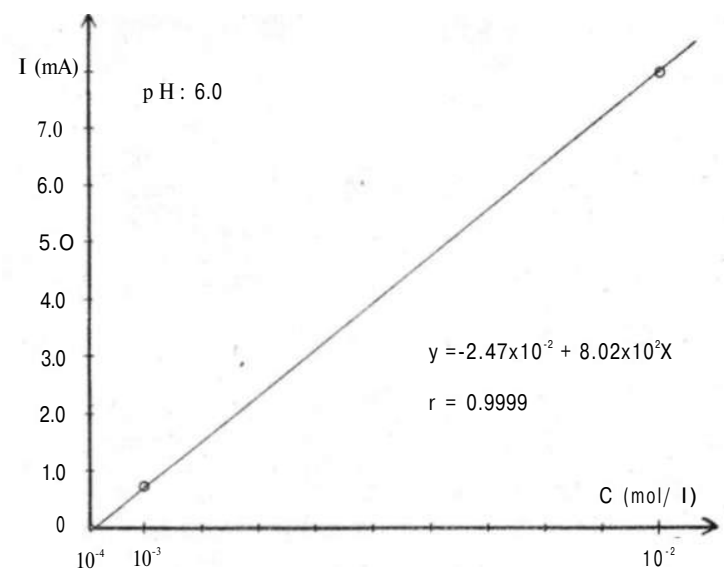

Şek 9a) Şek. 9 daki sınır akımı-konsantrasyon ilgisi.

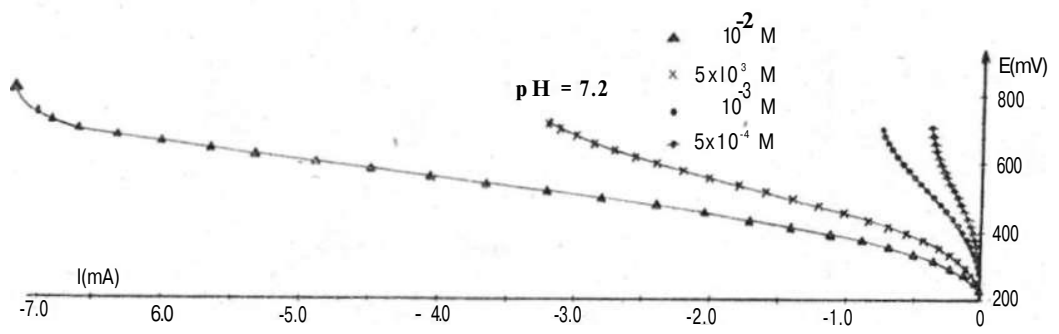

Şek. 10) $5.10^{-4}{ }^{10-2} \mathrm{M}$ hidrokinon + fosfat tamponu +1 M KCI $(\mathrm{PH}=7,2)$ içeren çözeltideki polarizasyon eğrileri.

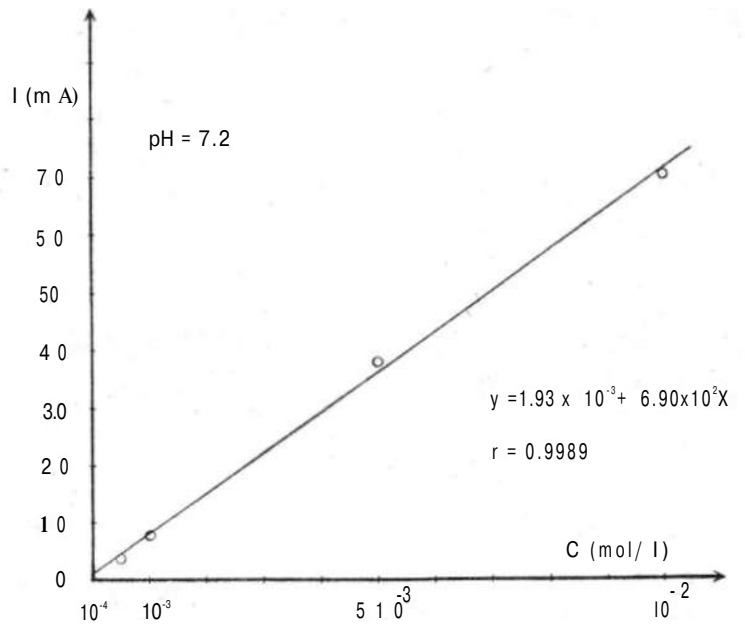

Şek. 10a) Şek. 10 daki sınır akımı-konsantrasyon ilgisi. 
Tablo 1. Kalibrasyon eğrilerinin çiziminde kullanılan sınır akımı değerleri.

\begin{tabular}{|c|c|c|c|}
\hline $\mathrm{pH}$ & $\begin{array}{c}\text { Hidrokinon } \\
\text { konsantrasyonu }\end{array}$ & $\begin{array}{c}\text { Sınır akımı }(\mathrm{mA}) \text { destek } \\
\text { elektroliti içerisindeki } \\
\text { akım çıkarılmış } \\
\text { eğrilerden }\end{array}$ & $\begin{array}{l}\text { Potansiyel } \\
\operatorname{aral}_{1} \breve{g}_{1}(\mathrm{mV})\end{array}$ \\
\hline 0.2 & $\begin{array}{cc}10^{-2} & X \\
10-^{-3} & \\
2.10^{-3} & \\
5.10^{-3} & \\
10^{-2} & \end{array}$ & $\begin{array}{l}0.15 \\
0.78 \\
1.35 \\
3.72 \\
8.10\end{array}$ & -1150 \\
\hline 2.9 & $\begin{array}{c}5.10^{-4} \\
10^{-3} \\
\mathbf{5 . 1 0} 0^{-3} \\
10^{-2}\end{array}$ & $\begin{array}{l}0.4 \\
0.85 \\
4.37 \\
8.80\end{array}$ & $1000-1050$ \\
\hline 4.5 & $\begin{array}{c}5.10^{-4} \\
10^{-3} \\
5.10^{-3} \\
10^{-2}\end{array}$ & $\begin{array}{l}0.33 \\
0.79 \\
3.85 \\
7.25\end{array}$ & $900-1000$ \\
\hline 6.0 & $\begin{array}{l}10^{-3} \\
10^{-2}\end{array}$ & $\begin{array}{l}0.75 \\
8.00\end{array}$ & $800-850$ \\
\hline 7.2 & 5. $\begin{array}{c}10^{-3} \\
\mathbf{1 0}^{-3} \\
10^{-2}\end{array}$ & $\begin{array}{l}0.40 \\
0.75 \\
3.25 \\
7.00\end{array}$ & $700-750$ \\
\hline
\end{tabular}

$\mathrm{Bu}$ araştırmada hidrokinonun rutenyum elektrotla anodik oksidasyonu incelenmiş ve kantitatif tayin koşulları saptanmışır. Hidrokinonun hidrojen adsorpsiyon potansiyellerinde ön işlem uygulanmış platin ve rutenyum elektrotlarla elde edilen oksidasyon eğrileri karşılaştırıldı̆̆ında rutenyum elektrotla elde edilmiş eğrilerdeki akım yoğunluğunun daha büyük olduğu gözlenmektedir. Bu da hidrojennin rutenyum yüzeyinde platin yüzeyinde olduğundan daha zayıf adsorplanmış olduğunu ve oksidasyon olayını engellemediğini kanıtlamaktadir.

Polarizasyon eğrileri aynı zamanda rutenyumun çeşitli yüzey oksitlerinin elektronik iletken olduğunu ortaya çıkarmaktadir. Deney sonuçlarına göre değişik pH larda hidrokinon konsantrasyonu ile sinır akımları arasında $10^{-4}-10^{-2} \mathrm{M}$ hidrokinon konsantrasyonu aralığında doğrusal bir ilişki vardır. Böylece bu yöntemle bu konsant- 
rasyon aralı̆̆ında hidrokinonun kantitatif tayininin yapılabileceği de saptanmıştır.

\section{S U M M A R Y}

In this research the anodic oxidation of hydroquinone was investigated using ruthenium electrode and the conditions under which the quantitative analysis of hydroquinone can be performed were determined.

When the oxidation curves of hydroquinone which were obtained using platinum and ruthenium electrodes, prepolarized at hydrogen adsorbtion potential, were compared, it was observed that the current density on the curves of ruthenium electrode were higher than those of platinum. This confirmes that hydrogen was less strongly adrosbed by the ruthenium surface than by the platinum surface and does not hinder the oxidation reaction.

The polarization curves also reveal that the various surface oxides of ruthenium are electronically conductive. According to the results of experiments for various $\mathrm{pH}$ values, the relation between the hydroquinone concentrations and the limiting currents is linear between $10^{-4} \mathrm{M}$ and $10^{-2} \mathrm{M}$ hydroquinone concentrations, this method thus can be used for quantitative determination of hydroquinone at this concentration range.

\section{L İ T E R A T Ü R}

1- Sandstede, G., (Editor), From Electrocatalysis to Fuel Cells, University of Washington Press 50, (1972).

2- Breiter, M.W., Electrochemical Processes In Fuel Cells, Springer Verlag 52, (1969).

3- Frumkin, A.N., Petery, O.A., Electrochim. Acta., 15,391, (1970).

4- Delahay, P., New Instrumental Methods in Electrochemistry, Interscience Publishers 115, (1954).

5- Fraunhofer von J.A., Banks, C.H., Potentiostat and its applications, Butterworths 141, (1972).

6- Thrisk, H.R., Harrison J.A., A Guide to the Study of Electrode Kinetics, Academic Press 1, (1972).

7- Pourbaix, M., Atlas of Electrochemical Equilibria in Aqueous Solution, Pergamon Press, 343, (1966).

8- Ödün, İ., Üneri, S., Commun. Fac. Sci. Univ. D'Ankara. 20 B, 63, (1973).

9- Kabasakaloğlu, M., Üneri, S., Commun. Fac. Sci. Univ. D'Ankara, 14 B, 23, (1967). 